This item was submitted to Loughborough's Research Repository by the author.

Items in Figshare are protected by copyright, with all rights reserved, unless otherwise indicated.

\title{
Hydrothermal carbonization of primary sewage sludge and synthetic faeces: Effect of reaction temperature and time on filterability
}

\section{PLEASE CITE THE PUBLISHED VERSION}

http://dx.doi.org/10.1002/ep.12114

\section{PUBLISHER}

(c) Wiley

\section{VERSION}

AM (Accepted Manuscript)

\section{PUBLISHER STATEMENT}

This work is made available according to the conditions of the Creative Commons Attribution-NonCommercialNoDerivatives 4.0 International (CC BY-NC-ND 4.0) licence. Full details of this licence are available at: https://creativecommons.org/licenses/by-nc-nd/4.0/

\section{LICENCE}

CC BY-NC-ND 4.0

\section{REPOSITORY RECORD}

Danso-Boateng, Eric, R.G. Holdich, Andrew D. Wheatley, Simon J. Martin, and Gilbert Shama. 2016. "Hydrothermal Carbonization of Primary Sewage Sludge and Synthetic Faeces: Effect of Reaction Temperature and Time on Filterability”. figshare. https://hdl.handle.net/2134/21467. 


\section{Hydrothermal Carbonisation of Primary Sewage Sludge and Synthetic Faeces: Effect of Reaction Temperature and Time on Filterability}

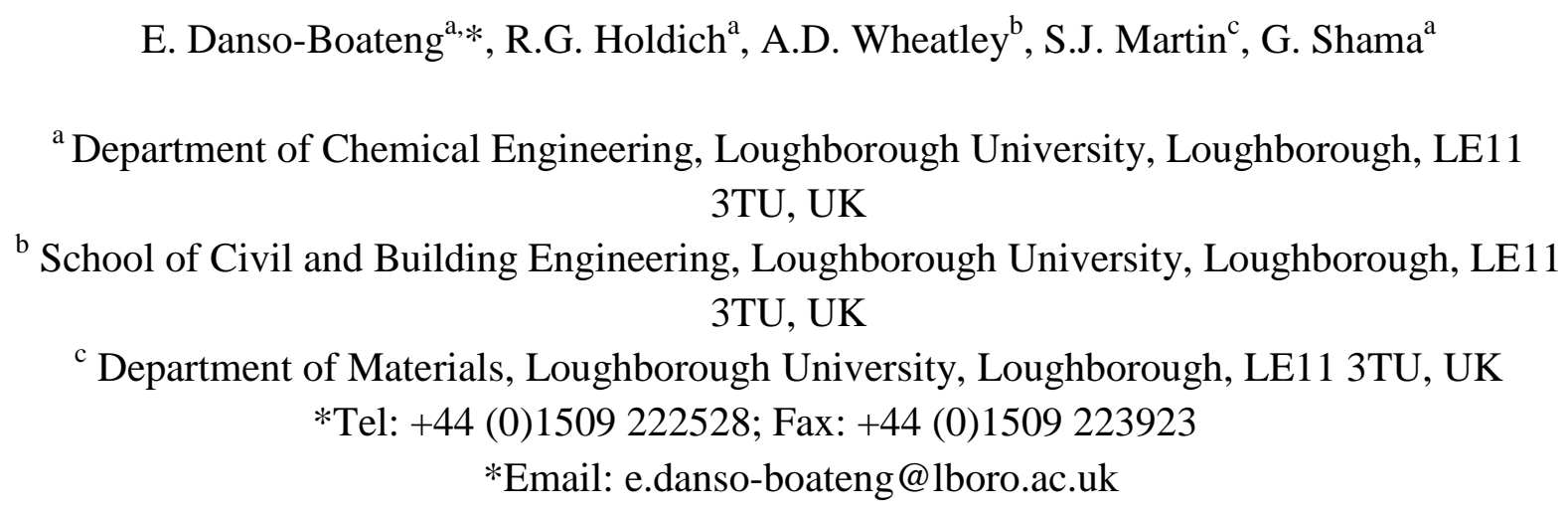

\section{ABSTRACT}

The effect of reaction temperature and time on the filterability of slurries of primary sewage sludge (PSS) and synthetic faeces (SF) following hydrothermal carbonisation (HTC) was investigated and optimised using response surface methodology (RSM). Filterability was shown to improve as the treatment temperature and reaction time at which the solids were carbonised was increased. The best filtration results were achieved at the highest temperature $\left(200^{\circ} \mathrm{C}\right)$ and longest treatment time ( $\left.240 \mathrm{~min}\right)$ employed here. The specific cake resistance to filtration of the carbonised solids was found to vary between $5.43 \times 10^{12}$ and $2.05 \times 10^{10} \mathrm{~m}$ $\mathrm{kg}^{-1}$ for cold filtration of PSS, $1.11 \times 10^{12}$ and $3.49 \times 10^{10} \mathrm{~m} \mathrm{~kg}^{-1}$ for cold filtration of SF, and $3.01 \times 10^{12}$ and $3.86 \times 10^{10} \mathrm{~m} \mathrm{~kg}^{-1}$ for hot filtration of SF, and decreased with increasing reaction temperature and time for carbonisation. There was no significant difference in the specific resistance of cold and hot filtration for SF. The RSM models employed here were found to yield predictions that were close to the experimental results obtained and should therefore prove useful in designing and optimizing HTC filtration systems for generating solids for a wide variety of end uses.

Keywords: Sludge Treatment, Dewaterability; Filtration; Hydrochar; Specific Cake Resistance. 
40 Nomenclature

41 A cross sectional area (m)

$42 \quad \mathrm{C}_{\mathrm{w}} \quad$ solid concentration by weight fraction (w/w)

43 C dry mass of solids per unit volume $\left(\mathrm{kgm}^{-3}\right)$

$44 \quad \mathrm{M} \quad$ mass of slurry filtered (g)

$45 \mathrm{Q} \quad$ volumetric rate of flow $\left(\mathrm{m}^{3}\right)$

$46 \quad \mathrm{R}_{\mathrm{m}} \quad$ medium resistance $\left(\mathrm{m}^{-1}\right)$

47 s mass fraction of solids in slurry (g)

$48 \quad \mathrm{~s}_{\mathrm{f}} \quad$ solids in filtrate (\% wt.)

$49 \mathrm{~T} \quad$ reaction temperature $\left({ }^{\circ} \mathrm{C}\right)$

$50 \mathrm{t}$ filtration time (s)

$51 t_{R} \quad$ reaction or treatment time (min)

$52 \mathrm{~V} \quad$ volume of filtrate $\left(\mathrm{m}^{3}\right)$

53

$54 \quad$ Greek letters

$55 \quad \alpha \quad$ specific cake resistance $\left(\mathrm{mkg}^{-1}\right)$

$56 \Delta \mathrm{P} \quad$ pressure drop $(\mathrm{Pa})$

$57 \mu \quad$ liquid viscosity (Pa s)

58

59 Abbreviations

60 CCRD central composite rotatable design

61 HTC hydrothermal carbonisation

62 PSS primary sewage sludge

63 RSM response surface methodology

64 SF synthetic faeces

65

66

67

68

69

70

71 


\section{INTRODUCTION}

The treatment and disposal of sewage sludge presents a number of environmental challenges [1-3]. Current practice is either to dispose of treated sludges to agricultural land [4], or either to incinerate [5] or landfill [6] them. Hydrothermal carbonisation (HTC) is a promising method of processing sewage sludge that results in the formation of a stable and sanitised product [7]. HTC does not require a dry feedstock, which makes it especially suitable for naturally wet biomass $[8,9]$. The process is self-contained and hence emission of greenhouse gases (GHG) is minimal. Indeed its implementation could actually result in GHG mitigation if the carbonized solids are used as soil conditioner $[7,10]$. The carbonaceous solid produced by HTC is commonly referred to as 'hydrochar', and in addition to this product an aqueous fraction is formed along with a small quantity of gas. Carbonisation is typically achieved at moderate temperatures $\left(180-250^{\circ} \mathrm{C}\right)$ under saturated pressures $[9,11]$. The hydrochar, which is the main product, has $\mathrm{H} / \mathrm{C}$ and $\mathrm{O} / \mathrm{C}$ ratios similar to that of coal and a heating value comparable to low rank coal [12] thus enabling it to be used as fuel. The hydrochar is a carbon-rich compound that is slow to oxidise, and it can be added to soil to sequester carbon that would otherwise be released into the atmosphere as GHG. Moreover, it has been shown to improve soil fertility [8]. Other options for the solids produced include biofuel production by transesterification [13], and gasification for syngas production [14]. These options require different ratios of $\mathrm{O} / \mathrm{C}$ for optimal operation, giving rise to different reaction temperatures and time requirements during HTC. After processing, the carbonised slurry needs to be dewatered to separate the hydrochar from the liquid product irrespective of its final use.

Previous work on biomass carbonisation $[9,11,15]$ has tended to focus on the chemistry and mechanisms of the HTC process, and how it can be used to produce various solid products for carbon sequestration, as an energy source or for other purposes [16-19]. However, efficient recovery of the hydrochar has hitherto not received attention, and hence, a more comprehensive study into HTC-slurry dewaterability is required in order to identify the optimum conditions and to determine the filteration properties of the dewatered products.

Such data would facilitate proper design and scale-up of filtration systems which may operate at different conditions of temperature and time, depending on the required solids to be 
produced. Yukseler et al. [20] proposed a model for filterability of sludge, but this is of limited usefulness in this context as the slurry used was not thermally treated, and its filtration characteristics would be markedly different from that of thermally treated sludges. Ramke et al. [21] studied the dewatering properties of various organic wastes (municipal waste, agricultural residues, etc.) following HTC. However, they did not optimise the process and therefore it is difficult to identify the conditions for best filterability. Finally, Yanagida et al. [22] undertook studies to predict the viscosity of sewage sludge following hydrothermal carbonisation over a range of conditions. However, their study did not extend to the dewatering of the end product.

The objectives of the work described here were to investigate the effects of HTC process temperature and treatment times on filterability of HTC-slurry, as well as the interaction effects among these operating conditions. Also, the influence of hot filtration on filterability was investigated for primary sewage sludge as well as a standard faecal simulant. The operating conditions for achieving the optimise filterability was examined using response surface methodology (RSM) models.

\section{MATERIALS AND METHODOLOGY}

\section{Primary Sewage Sludge and Faecal Simulant}

Primary sewage sludge (PSS), was collected from Wanlip Sewage Treatment Works (Leicestershire, UK). PSS primarily comprises faecal matter removed by settlement and typically contained 4.3\% (wt.) solids as received. A synthetic faeces (SF) was prepared using the formulation proposed by Wignarajah et al. [23]. The solids comprised cellulose (37.5\%), yeast (37.5\%), peanut oil (20\%), $\mathrm{KCl}(4 \%), \mathrm{Ca}\left(\mathrm{H}_{2} \mathrm{PO}_{4}\right)_{2}(1 \%)$ (all purchased from SigmaAldrich, UK), and tap water - which constituted 90\% (wt.) of the SF. The materials were uniformly mixed with water to form a suspension with $10 \%$ solids. These were prepared immediately before conducting the carbonisation tests. 


\section{Hydrothermal Carbonisation}

About $150 \mathrm{ml}$ of PSS, as received, was subjected to HTC using a $250 \mathrm{~mL}$ stainless steel batch reactor (BS1506-845B, UK) immersed in an oil bath (B7 Phoenix II, Thermo

Scientific, UK) containing Shell Thermia oil B (Shell, UK). The PSS was periodically stirred manually to prevent settling prior to carbonisation. HTCs were performed at reaction temperatures of $140,160,180$, and $200^{\circ} \mathrm{C}$. HTC at $140^{\circ} \mathrm{C}$ was carried out for $4 \mathrm{~h} ; 160^{\circ} \mathrm{C}$ for 1, 2 and $4 \mathrm{~h} ; 180^{\circ} \mathrm{C}$ for $0.5,1,2$ and 4 h; and $200^{\circ} \mathrm{C}$ for $0.25,0.5,1,2$ and 4 h. Further details of the HTC process may be found in a previous study [24], which reported the reaction kinetics and equilibrium solids mass remaining. The temperature range used here was selected so as to minimise energy requirement for the HTC system in order that the process would remain economical for developing countries. HTC of SF was performed at the same reaction temperatures and treatment times using a pilot scale semi-batch HTC reactor suitable for cold and hot filtration tests. Hot filtration tests were not possible for the batch PSS reactor system.

\section{Filterability}

\section{Cold Filtration of PSS}

After HTC had been completed, the reactor was cooled to about $25^{\circ} \mathrm{C}$ and the gaseous phase vented. The carbonised slurry (about $150 \mathrm{ml}$ ) was transferred to a clear filtration cell with a total volume of $300 \mathrm{ml}$ as represented in Figure 1 (a), and connected to a vacuum pump. Filtration was conducted using a metal microporous filter medium, with $10 \mu \mathrm{m}$ slotted pores and nominal thickness of $0.06 \mathrm{~mm}$, manufactured by Micropore Technologies Ltd. (Hatton, Derbyshire, UK). The vacuum was applied by means of a vacuum pump (CAPEX placed on an electronic balance (TP2KV, OHAUS Corporation, USA). The weight of the 
filtrate with respect to time was recorded using a PC customised Labview software. In all the experiments, the vacuum pressure was set to $58.6 \mathrm{kPa}$ using a needle valve. The filter medium was cleaned after each experiment with a detergent using a sonic bath, prior to reuse in further tests.

\section{Cold and hot Filtration of SF}

After HTC, the reactor was allowed to cool down to $25^{\circ} \mathrm{C}$ or flashed to $100^{\circ} \mathrm{C}$ for cold and hot filtration, respectively. Valve-1 was opened to transport the carbonised slurry (about $450 \mathrm{ml}$ ) to the filtration cell (internal diameter of $55 \mathrm{~mm}$ and total volume of $535 \mathrm{ml}$ ) connected to the reactor as shown in Figure 1 (b). The pressure in the cell and reactor was adjusted to obtain a filtration pressure between $61.0-78.7 \mathrm{kPa}$. Filtration was started immediately by opening Valve-2 and the weight of the filtrate with respect to time was recorded. The material was filtered using the same filter medium, electronic balance and PC customised with Labview software as explained in cold filtration of PSS.

\section{Analysis of Total Solids in Filtrate}

Total solids leached into the filtrate during HTC and filtration were analysed according to EPA method, 1684, by heating about $25 \mathrm{~g}$ of each sample in an oven at $103 \pm 2{ }^{\circ} \mathrm{C}$ for $1 \mathrm{~h}$ to dry. Total solids in weight percent, was calculated as the percentage weight difference before and after oven drying [25]. All analyses were performed in triplicate.

\section{Analysis of Total Organic Carbon in Filtrate}

Total organic carbon (TOC) in the filtrate was analysed using a TOC analyser (DC-190, Rosemount Dohrmann, USA), according to Standard Methods 5310 B - High Temperature Combustion Method [26]. The analysis was carried out in two ways: first, the filtrates were directly analysed for TOC. In the second test, the filtrates were further filtered using filter 
paper (Whatman Grade 2) to obtain suspended and colloidal/dissolved solids. The samples were diluted to a ratio of $1: 10$, and a $50 \mu \mathrm{L}$ aliquot injected in to the instrument chamber to analyse total and inorganic carbon. The TOC was obtained by subtraction of inorganic carbon (if any) from the total carbon. Triplicate measurements were made, and the average and standard deviations calculated.

\section{Experimental Design}

Response surface methodology (RSM) using a central composite rotatable design (CCRD) was used to study the influence of the two variables (reaction temperature, and retention time) and their interaction on the filterability of HTC-slurry. Design Expert 9.0.1 software (Statease, Minneapolis, MN) for the CCRD and statistical analysis of variance (ANOVA), which resulted in 13 tests ( 4 factorial points, 4 star points, and 5 central points). Each variable was set at 5 levels: $-\alpha,-1,0,1$ and $\alpha$ (where $\alpha=1.414$ ).

\section{RESULTS AND DISCUSSION}

\section{Filtrate Volume}

Figures 2 and 3 show that, for both SF and PSS, the amount of liquid recovered following HTC increased as the reaction temperature and treatment time were increased. Higher volumes of filtrate were obtained at shorter filtration times from slurries carbonised at higher temperatures for longer retention times. For instance, about $125 \mathrm{ml}$ of filtrate was obtained in $1 \mathrm{~min}$ from cold filtration of PSS slurry carbonised at $200^{\circ} \mathrm{C}$ for $240 \mathrm{~min}$, compared with about $17 \mathrm{ml}$ obtained in $1 \mathrm{~min}$ for $\mathrm{HTC}$ at $200^{\circ} \mathrm{C}$ for $15 \mathrm{~min}$ (see Figure 3-d). Hot filtration of SF was faster than cold filtration of SF. For example, within $10 \mathrm{~s}$ of hot filtration, 170 and $196 \mathrm{ml}$ of filtrate were obtained for slurries from $\mathrm{HTC}$ at $180^{\circ} \mathrm{C}$ and $200^{\circ} \mathrm{C}$ both for 240 min respectively, compared with about $70 \mathrm{ml}$ obtained for cold filtration in both cases. Due to differences in size of the HTC reactors used here for filtration of PSS, $150 \mathrm{ml}$ 
of slurry (containing about $145 \mathrm{ml}$ of liquid) was transferred to the filtration cell, whereas 450 ml of slurry (with about $428 \mathrm{ml}$ of liquid) was transferred to the filtration cell for SF (cold and hot) filtration. For SF, in order to achieve a minimum filtration pressure that would enable measurement of the filtrate volume per time, the HTC reactor was flashed: i.e. the over-pressure required to prevent the water boiling during the HTC process was rapidly released, resulting in a process fluids temperature of approximately $100^{\circ} \mathrm{C}$ being rapidly achieved.

The linear equation represented by Eq. (4) gives the t/V versus V plots presented in Figure 4. The plots illustrate typical sets of data obtained from a constant pressure filtration method. For slurries from HTC at $200^{\circ} \mathrm{C}$, good linearity was obtained for PSS and SF (cold filtered, and hot filtered) at all treatment times (15-240 min). At lower temperatures and also shorter treatment times, the slope of the $\mathrm{t} / \mathrm{V}$ versus $\mathrm{V}$ plots increased rapidly (as shown in Figure 4-a, -b, and -c). This occurred when the filtration behavior was poor, due to poorly filtering solids and/or filter medium blockage.

\section{Filtration Resistance}

During filtration a porous cake builds up on the porous filter medium and further filtration takes place at the top surface of that cake. By applying Darcy’s law the pressure drop across the filter medium is:

$$
\Delta \mathrm{P}=\left(\frac{\mu \mathrm{R}}{\mathrm{A}}\right)\left(\frac{\mathrm{dV}}{\mathrm{dt}}\right)
$$

Addition of the medium and filter cake pressure drop provides the classical linear equation for constant pressure filtration:

$$
\frac{t}{V}=\frac{\mu \alpha c}{2 A^{2} \Delta P}(V)+\frac{\mu R_{m}}{A \Delta P}
$$

$\mathrm{R}_{\mathrm{m}}$ and $\alpha$, are the resistance of the filter medium and filter cake, and may be evaluated from the intercept and slope of the t/V vs. V plot, respectively. 

cake by the mass of wet cake. method for determining specific cake resistance to filtration, from constant pressure filtration are presented in Figure 4. Theoretically, the plot of t/V versus V gives a straight line (see Figure 4) with

$$
\text { slope }=\frac{\mu \alpha c}{2 \mathrm{~A}^{2}(\Delta \mathrm{P})}
$$

and

$$
\text { intercept }=\frac{\mu \mathrm{R}_{\mathrm{m}}}{\mathrm{A}(\Delta \mathrm{P})}
$$

For cold filtration of PSS and SF, the viscosity of water at $25^{\circ} \mathrm{C}$ was used, whilst that at $100^{\circ} \mathrm{C}$ was used for hot filtration of SF in both Eqs. (5) and (6). The dry cake mass per unit volume of filtrate at the end of the filtration, c was calculated from knowledge of the filtrate volume (V) and the mass fraction of solids in the slurry (s) and mass of slurry filtered (M):

$$
\mathrm{c}=\frac{\mathrm{sM}}{\mathrm{V}}
$$

Specific cake resistance is a measure of filterability or dewaterability; the lower the specific resistance, the greater the dewaterability of a slurry [27]. As shown in Figure 5, values of specific cake resistance to filtration decreased as HTC temperature and reaction time increased. For PSS, filterability is greater for slurry from HTC at $200^{\circ} \mathrm{C}$ for $240 \mathrm{~min}$ treatment time ( $\alpha=2.05 \times 10^{10} \mathrm{~m} \mathrm{~kg}^{-1}$ ), though the slurry from 15 min treatment time filtered fairly well $\left(\alpha=7.62 \times 10^{11} \mathrm{~m} \mathrm{~kg}^{-1}\right)$. The filterability of PSS slurry from HTC at $180^{\circ} \mathrm{C}$ ranged from $3.32 \times 10^{11}-1.55 \times 10^{11} \mathrm{~m} \mathrm{~kg}^{-1}$ for treatment times between $120-240 \mathrm{~min}$ respectively, but no filter cake was formed between 30-60 min treatment times. Except for HTC at $160^{\circ} \mathrm{C}$ and $240 \mathrm{~min}\left(\alpha=5.43 \times 10^{12} \mathrm{~m} \mathrm{~kg}^{-1}\right)$, cake filtration of PSS slurries from HTC at lower temperatures were not possible, as no filter cakes were formed. As a result, values 
of specific cake resistance in these cases were not included in Figure 5 (a). Specific cake resistance to filtration of raw sludge is reported to vary from $1.0-2.9 \times 10^{14} \mathrm{~m} \mathrm{~kg}^{-1}$ [28]. Values of specific cake resistance to filtration exceeding $1.0 \times 10^{12} \mathrm{~m} \mathrm{~kg}^{-1}$ indicate poor filterability [29]. The poor filterability of slurries from HTC at lower temperatures indicated that the slurries were not well carbonised. In a previous study using identical feedstocks it was shown that conversion of solids to hydrochar is less favoured at lower temperatures and also for shorter retention times [24]. The carbonised cake has a fibrous porous structure with increased porosity. Previous studies indicate that hydrothermal treatment affects the structure of the carbonised solids, and the effect depends on the treatment temperature [30,31]; even though none of the studies relate this to filterability of the end product. The disruption of the colloidal structure and increase in porosity of the carbonised cake accounted for the greater filterability especially at higher temperatures.

Specific cake resistance for cold and hot-filtered SF are comparable, especially for slurry from $\mathrm{HTC}$ at $200^{\circ} \mathrm{C}$; with values ranging from $8.14-3.49 \times 10^{10} \mathrm{~m} \mathrm{~kg}^{-1}$ and $3.08-3.86 \times 10^{10}$ $\mathrm{m} \mathrm{kg}^{-1}$ for cold and hot filtration respectively, between 15-240 min treatment times. The viscosity of the liquid affects the rate at which the filtrate permeates through the filter and the cake. As the temperature increased, the viscosity of the liquid fraction decreases, and consequently the overall resistance to filtration of hot-filtered SF slurry should be lower than that of cold-filtered SF. However, there was no significant difference between hot and cold filtration of SF on the resulting specific resistance; although hot filtration was observed to be faster as would be expected by a lower viscosity filtrate. Specific cake resistance to filtration of hot-filtered SF slurries from $\mathrm{HTC}$ at $160^{\circ} \mathrm{C}$ and treatment times between $60-120$ min were between $1.58 \times 10^{12}-3.01 \times 10^{12} \mathrm{~m} \mathrm{~kg}^{-1}$; similar to that obtained for cold-filtered SF feedstock $\left(1.32 \times 10^{12} \mathrm{~m} \mathrm{~kg}^{-1}\right)$, the calculation for specific resistance takes in to account different liquid viscosities. 

temperatures and shorter treatment times; and decreased as HTC temperature and time of PSS slurry than cold filtered SF. This may be due to differences in the characteristics of the two feedstock materials. Resistance of the filter medium for $\mathrm{HTC}$ at $200^{\circ} \mathrm{C}$ and $15-240$ min treatment times ranged between $3.33 \times 10^{10}-2.78 \times 10^{10} \mathrm{~m}^{-1}, 5.65 \times 10^{9}-9.91 \times 10^{9} \mathrm{~m}^{-1}$, $1.47 \times 10^{10}-0.39 \times 10^{10} \mathrm{~m}^{-1}$ for cold filtration of PSS, cold, and hot filtration of SF respectively. The higher medium resistance of hot-filtered SF slurry than that of cold-filtered SF slurry may have been caused by fouling of the filter surface with the hazy liquid of the former containing more solids in the filtrate which is explained in the subsequent section.

\section{Solids Leached into Filtrate}

Generally, very small amounts of solids were found in the filtrate since the filtration was conducted on an open-slotted filter medium. However, filtration of slurry carbonised at higher HTC temperature and longer treatment time resulted in less solids leached into the filtrate, with decreasing solids as HTC temperature and time increased (see Table 1). More solids were found in the filtrate when the SF was hot-filtered than when it was cold-filtered. Total solids in the filtrate ranged between 1.92-1.68 \% (wt.) and 2.83-1.98 \% (wt.) for cold and hot-filtration of SF between HTC temperatures of $160-200^{\circ} \mathrm{C}$, respectively. In effect, filtrate from hot-filtered SF was hazy, because it contain more colloidal soluble components especially at HTC temperatures between $160^{\circ} \mathrm{C}$ and $180^{\circ} \mathrm{C}$ (see Figure 5-b and -c). As and $60-120$ min treatment times $\left(3.01 \times 10^{12}-1.58 \times 10^{12} \mathrm{~m} \mathrm{~kg}^{-1}\right)$ were similar to that obtained for SF feedstock $\left(1.32 \times 10^{12} \mathrm{~m} \mathrm{~kg}^{-1}\right)$. 
Table 1 shows the effect of treatment temperature and time on total organic carbon (TOC) in the filtrate following cold filtration of carbonised PSS slurries. As explained in the TOC analysis, the test was performed in two ways: first, the filtrates were directly analysed following filtration with the $10 \mu \mathrm{m}$ slotted filter medium. In the second test, the filtrates were further filtered using Whatman filter paper. The TOC from the first tests appeared to vary randomly. This may be due to residual colloidal carbon that may have passed through the slotted filter and was detected by the TOC analyzer. A micro needle was used to take filtrate samples for analysis; any form of colloidal particles taken up by the needle that is analysed would cause significantly fluctuating results. TOC determined after the filtrates were further filtered (second tests) was more consistent and increased systematically as the treatment temperature and time were increased (see Table 1). The subsequent filtration ensured complete removal of suspended and colloidal solids in the filtrates; hence TOC reported here is solely that of dissolved solids. The increase in TOC as the treatment temperature and time increased is due to increasing dissolved carbon into the filtrate as the process severity increased.

\section{Cake Concentration}

Figure 7 shows the effect of reaction temperature and time on cake concentration by weight for cold filtered PSS, and cold and hot filtered SF. Cake concentration was highest at higher reaction temperatures and longer treatment times, and increased as the temperature and time increased. Hot filtration of SF produced the driest cake (i.e. highest cake concentration) with values between 35-58 \% (w/w), followed by cold filtration of SF (26-45 $\% \mathrm{w} / \mathrm{w})$, and that for cold filtration of PSS varying between $14-27 \%(w / w)$. For PSS, filtration was not possible for slurries carbonised at the lower reaction temperatures (140$160^{\circ} \mathrm{C}$, except that for $160^{\circ} \mathrm{C}$ and 240 min treatment times), and $180^{\circ} \mathrm{C}$ at shorter treatment times (30 and $60 \mathrm{~min}$ ) as no cake was formed during the filtration on the slotted $10 \mu \mathrm{m}$ filter. A high cake solids content is desired to stabilise the hydrochar (i.e. carbonised solids) for storage or transportation. Although filtrate from hot filtration of SF contains more solid 
particles, depending on process objectives hot filtration would be the optimum option, particularly if the filtrate is to be reused or digested, e.g. by anaerobic means, as this contains more dissolved organic components.

\section{ANOVA, Modelling and Optimisation of Filterability}

Model Fitting and ANOVA

RSM models developed using Design-Expert 9.0.1 software, and ignoring insignificant terms, provide the constituent equations given in Eqs. (8-21) in terms of coded variables, which are presented in Table 2 for filtrate volume, specific cake resistance of filter cake, resistance on filter medium, cake volume concentration and solids leached into filtrate.

From the results of the analysis of variance (ANOVA) (see Tables S1-S3) for filtrate volume, regression analysis of the experimental design showed that the linear model terms ( $\mathrm{T}$ and $\left.t_{R}\right)$ were highly significant $(P<0.05)$ for cold filtration of PSS and hot filtration of SF; whilst the linear model term $(T)$, interactive model term $\left(T t_{R}\right)$, and quadratic term $\left(T^{2}\right)$ were significant for cold filtration of SF (other terms did not show significant effect). Specific cake resistance for cold filtration of PSS was strongly influenced by the linear model term (T) (other terms did not show significant effect); whilst cold of SF was strongly influenced by the linear model term $(\mathrm{T})$, and interactive term $\left(\mathrm{Tt}_{\mathrm{R}}\right)$; although hot filtration of SF was highly affected by linear model terms ( $T$ and $\left.t_{R}\right)$, and interactive term $\left(T t_{R}\right)$.

The resistance provided by the medium for cold filtration of PSS was significantly affected by the linear model terms $\left(T\right.$ and $t_{R}$ ), whilst that of hot-filtered $S F$ has temperature as the only significant term as presented in Eq. (15). A model equation is not presented in the case of cold filtration of SF as there are no significant model terms. For cake concentration from cold filtration of PSS, there were no significant model terms and therefore no model equation is presented here. As explained in Section 3.5, cake concentration of PSS was not possible at lower treatment temperatures, and thus the model was developed taking into 
consideration only data for $\mathrm{HTC}$ at $160^{\circ} \mathrm{C}$ and 240 min treatment time and at higher HTC

temperatures. Cake concentrations of cold- and hot-filtered SF were affected by linear model terms ( $T$ and $t_{R}$ ). A linear model (Eq. (19)) was developed for total solids leached into filtrate during cold filtration of PSS, which was affected by the linear model terms ( $T$ and $\left.t_{R}\right)$.

Similarly, solids in filtrate for cold and hot filtration of SF were only influenced by the linear model term $\left(t_{R}\right)$. The temperature term did not show a significant effect.

The significant $P$-values $(P<0.05)$ showed that the models were suitable and reliable, with the exception of medium resistance and cake concentration for cold filtration of PSS, as well as solids in the filtrate for cold and hot filtration of SF that have insignificant model terms $(P>0.05)$. The models developed in this study are useful in specifying the effect of each significant term and their interaction on the target variables, and thus the results provide information useful for filtration of HTC-slurry from biomass.

\section{Optimisation and Validation}

The optimum HTC operating conditions for greater filterability from the RSM models and results of validation experiment for specific cake resistance to filtration, resistance of medium, cake concentration and solids in filtrate are illustrated in Figure 8. The models were validated under the same optimal conditions to check their accuracy. For comparison, other validated results at lower operating conditions are also presented in Figure 8. The minimum specific cake resistance to filtration of $1.70 \times 10^{10} \mathrm{~m} \mathrm{~kg}^{-1}, 5.04 \times 10^{10} \mathrm{~m} \mathrm{~kg}^{-1}$, and $3.02 \times 10^{10}$ $\mathrm{m} \mathrm{k}^{-1} \mathrm{~g}$ were predicted at the highest temperature $\left(200^{\circ} \mathrm{C}\right)$ with the longest treatment time (240 min) for cold filtration of PSS, cold filtration of SF, and hot filtration of SF, respectively. Experimental results at the same optimal conditions were $2.05 \times 10^{10-1}, 3.29 \mathrm{x}$ $10^{10}$, and $3.86 \times 10^{10} \mathrm{~m} \mathrm{~kg}^{-1}$ for cold filtration of PSS, cold filtration of SF, and hot filtration of SF, respectively. For cold and hot filtration of SF, experimental results obtained at $200^{\circ} \mathrm{C}$ and shorter treatment time (60 min) were closer to the predicted values; with errors of $26 \%$ 
and $7 \%$ than that for 240 min treatment time having errors of $35 \%$ and $28 \%$ respectively. The experimental results were close to the predicted results and confirmed the validity of the model. Based on the model, the lowest medium resistance of $1.20 \times 10^{11}, 1.18 \times 10^{10}$, and $0.54 \times 10^{10} \mathrm{~m}^{-1}$ were at $200^{\circ} \mathrm{C}$ and 240 min treatment time, with the accuracy of the model strongly confirmed for cold and hot filtration of SF (error between 16-27\%).

The highest cake concentrations of $0.29,0.44$, and $0.54(\mathrm{w} / \mathrm{w})$ were predicted at $200^{\circ} \mathrm{C}$ and 240 min for cold-filtered PSS, cold-filtered SF, and hot-filtered SF respectively; which were confirmed by the validation experiments with differences of between 2-7\%. Similarly, solids in filtrate of $1.41 \%, 1.53 \%$, and $2.00 \%$ were predicted at $200^{\circ} \mathrm{C}$ and $240 \mathrm{~min}$. The difference between the experimental results and predicted results were less than $1 \%$, which makes the predicted results validated by the actual values.

When designing industrial processes with filtration stages, i.e. scaling up, it is common to apply a constituent equation relating the specific resistance to filtration with some operating condition, such as operating pressure [32]. In the case of filtration of material from the hydrothermal carbonisation process the significant operating condition is temperature, and Table 2 provides the constitutive equations that can be used to relate the specific resistance to this parameter. Table 2 provides similar constitutive equations for the other parameters required for industrial design: filter medium resistance and cake concentration. Using these three constituent equations it is possible to predict the performance of any type of industrial operating mode for filtration: constant pressure, constant rate, or variable pressure and rate; provided that the other system dependent parameters are also supplied: filter area and operating pressure (as well as the viscosity of water at the appropriate temperature). The equation used for the prediction depends on the filtration operating mode, but in every case it is possible to model the filtrate volume with time using these input parameters, together with the temperature dependent values obtained by RSM as shown in Table 2. Thus it is possible 
to model the influence of residence time and treatment temperature on the overall filtration

418 performance of the system; e.g. it is possible to determine the filter area required to achieve a given filtrate volume in a required time. Such information would be required if designing a process where the filtration stage needs to be completed before the addition of the next batch of carbonised slurry is filtered in a semi-batch system.

\section{CONCLUSIONS}

Results from the predicted RSM models and experimental data showed that the higher the reaction temperature and the longer the treatment time, the greater was the carbonised slurry’s filterability. Specific cake resistance to filtration decreased as reaction temperature and time increased. Dewatering the HTC-slurry whilst hot resulted in higher cake concentrations, although filterability was not concomitantly improved. Filterability of HTCslurry was shown to be highly influenced by reaction temperature and treatment time. Predictions were generally close to the validation results, which indicates that the models based on the RSM data are applicable for prediction and optimisation of HTC-slurry dewaterability. For example, in a process under design investigation there could be a desire to operate at a lower temperature to provide solids suitable for treatment to form bioethanol, whereas higher temperatures will provide greater quantities of carbonised solids more suitable for gasification and syngas production during further processing. This study provides quantitative information on the expected filterability of solids from the HTC process at temperatures between 140 and $200^{\circ} \mathrm{C}$. It can also be concluded that the synthetic faecal sludge does provide similar filtration resistance to the primary sewage sludge. Hence, processes can be justifiably developed using the simulant for preliminary testing. 


\section{ACKNOWLEDGEMENTS}

This research was part of Gates Foundation: "Reinventing The Toilet Challenge”. The

447 authors are thankful to Geoffrey Russell for his help with collection of primary sewage

448 sludge.

449

450

451

452

resistance, resistance of filter medium, cake concentration and solids in filtrate.

453

454

455

456

457

458

459

460

461

462

463

464

465

466

467

468

469

\section{LITERATURE CITED}

1. Jepsen, S-E., Krause, M., Grunter, H. (1997). Reduction of faecal streptococcus and Salmonella by selected treatment methods for sludge and organic waste. Water Sci. Technol., 36, 203-210.

2. WHO/UNICEF/WSSCC. (2000). Global Water Supply and Sanitation Assessment 2000 Report. WHO/UNICEF Joint Monitoring Programme for Water Supply and Sanitation, USA: Iseman Creative. ISBN 9241562021.

3. Sahlström, L., Aspan, A., Bagge, E., Danielsson-Tham, M-L., Albihn, A. (2004). Bacterial pathogen incidences in sludge from Swedish sewage treatment plants. Water Res., 38, 1989-1994.

4. Langergraber, G., Muellegger, E. (2005). Ecological Sanitation - a way to solve global sanitation problems? Environment International, 31, 433-444.

5. Schönning, C., Stenström, T.A. (2006). Guidelines on the Safe Use of Urine and Faeces in Ecological Sanitation Systems. EcoSanRes Publication Series, Report 2004-1, York, UK: Howard Cambridge.

6. Water UK. (2010). Recycling of biosolids to agricultural land. Issue number 3. 
7. Cantrell, K., Ro, K., Mahajan, D., Anjom, M., Hunt, P.G. (2007). Role of thermal conversion in livestock waste-to-energy treatments: Obstacles and opportunities. Ind. Eng. Chem. Res., 46, 8918-8927.

8. Titirici, M-M., Anotonietti, M., Thomas, A. (2007). Back in the black: hydrothermal carbonization of plant material as an efficient chemical process to treat the $\mathrm{CO}_{2}$ problem? New Journal of Chemistry, 31, 787-789.

9. Libra, J.A., Ro, K.S., Kammann, C., Funke, A., Berge, N., Neubauer, Y., Titirici, M-M., Fuhner, C., Bens, O., Kern, J., \& Emmerich, K-H. (2011). Hydrothermal carbonization of biomass residuals: A comparative review of the chemistry, processes and applications of wet and dry pyrolysis. Biofuels, 2(1), 89-124.

10. Antal, M.J., Gronli, M. (2003). The art, science, and technology of charcoal production, Ind. Eng. Chem. Res., 42(8), 1619-1640.

11. Funke, A., Ziegler, F. (2010). Hydrothermal carbonization of biomass: A summary and discussion of chemical mechanisms for process engineering. Biofuels, Bioprod. Bioref., 4, 160-177.

12. Demir, C.R., Titirici, M-M., Antonietti, M., Cui, G., Maier, J., Hu, Y-S. (2008). Hydrothermal carbon spheres containing silicon nanoparticles: synthesis and lithium storage performance. Chem. Commun., 32, 3759-3761.

13. Levine, R.B., Bollas, A., Savage, P.E. (2013). Process improvements for the supercritical in situ transesterification of carbonised algal biomass. Bioresource Technol., 136, 556564.

14. Castello, D., Kruse, A., Fiori, L. (2014). Supercritical water gasification of hydrochar. Chem. Eng. Res. Des., 92, 1864-1875.

15. Peterson, A.A., Vogel, F., Lachance, R.P., Fröling, M., Antal Jr, M.J., Tester, J. (2008). Thermochemical biofuel production in hydrothermal media: A review of sub- and supercritical water technologies. Energy \& Environmental Science, 1, 32-65. 
16. Reza, M.T., Lynam, J.G., Vasquez, V.R., Coronella, C.J. (2012). Pelletization of biochar from hydrothermally carbonised wood. Environ. Prog. Sustainable Energy, 31(2), 225234.

17. Yan, W., Hoekman, S.K., Broch, A., Coronella, C.J. (2014). Effect of hydrothermal carbonisation reaction parameters on the properties of hydrochar and pellets. Environ. Prog. Sustainable Energy, 33(3), 676-680.

18. Uddin, M.H., Reza, M.T., Lynam, J.G., Coronella, C.J. (2013). Effects of water recycling in hydrothermal carbonisation of loblolly pine. Environ. Prog. Sustainable Energy, 100, $1-7$

19. Levine, R.B., Sierra, C.O.S., Hockstad, R., Obied, W., Hatcher, P.G., Savage, P.E. (2013). The use of hydrothermal carbonisation to recycle nutrients in algal biofuel production. Environ. Prog. Sustainable Energy, 32(4), 962-975.

20. Yukseler, H., Tosun, I., Yetis, U. (2007). A new approach in assessing slurry filterability. Journal of Membrane Science, 303, 72-79.

21. Ramke, H-G., Blohse, D., Lehmann, H-J., Fettig, J. (2009). Hydrothermal carbonisation of organic waste. Twelfth International Waste Management and Landfill Symposium, Symposium in S. Margherita di Pola-Cagliari, Sardinia, Italy, 05-09 October 2009.

22. Yanagida, T., Fujimoto, S., Minowa, T. (2010). Application of the severity parameter for predicting viscosity during hydrothermal processing of dewatered sewage sludge for a commercial PFBC plant. Bioresour. Technol., 101, 2043-2045.

23. Wignarajah, K., Litwiller, E., Fisher, J., Hogan, J. (2006). Simulated human feces for testing human waste processing technologies in space systems, 36th International Conference on Environmental Systems, (pp. SAE paper no. 2006-01-2180), Norfolk, VA: Virginia, USA. 
24. Danso-Boateng, E., Holdich, R.G., Shama, G., Wheatley, A.D., Sohail, M., Martin, S.J. (2013). Kinetics of faecal biomass hydrothermal carbonisation for hydrochar production. Applied Energy, 111, 351-357.

25. USEPA. (2001). Total, Fixed, and Volatile Solids in Water, Solids, and Biosolids. Method 1684, EPA-821-R-01-015.

26. APHA. (2005). Standard Methods for the Examination of Water and Wastewater, 21st edition. Washington DC: APHA-AWWA-WEF.

27. USEPA. (1987). Design Manual-Dewatering Municipal Wastewater sludge, EPA/625/187/014, Cincinnati, Ohio.

28. Coackley, P., Wilson, F. (1971). Flocculation with special reference to water and wastewater engineering. Filtration Sep., 8(1), 61.

29. Rowe, D.R., Abdel-Magid, I.M. (1995). Handbook of Wastewater Reclamation and Reuse, Florida: Lewis publications.

30. Mumme, J., Eckervogt, L., Pielert, J., Diakité, M., Rupp, F., Kern, J. (2011). Hydrothermal carbonisation of anaerobically digested maize silage. Bioresource Technol., 102, 9255-9260.

31. Schneider, D., Escala, M., Supawittayayothin, K., Tippayawong, N. (2011). Characterization of biochar from hydrothermal carbonisation of bamboo. International Journal of Energy and Environment, 2, 647-652.

32. Rushton, A., Ward, A.S. and Holdich, R.G. (2000). Solid-Liquid Filtration and Separation Technology, Second Edition, Wiley-VC, Weinheim, Germany.

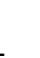

2

3

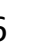




\section{Table 1}

550 Filtration properties of carbonised primary sewage sludge and synthetic faeces slurries.

551

552

Table 2

553 RSM model equations in terms of coded variables.

554

555

556

557

558

559

560

561

562

563

564

565

566

567

568

569

570

571

572

573

574

575

576

577

578

579

580 


\begin{tabular}{|c|c|c|c|c|c|c|}
\hline \multicolumn{2}{|c|}{$\begin{array}{c}\text { HTC } \\
\text { Parameters } \\
\end{array}$} & \multicolumn{3}{|c|}{ Cold-filtered PSS } & \multirow{2}{*}{$\begin{array}{c}\text { Cold- filtered SF } \\
\begin{array}{c}\text { Solids in filtrate } \\
(\% \text { wt. })\end{array}\end{array}$} & \multirow{2}{*}{$\begin{array}{c}\text { Hot-filtered SF } \\
\begin{array}{c}\text { Solids in filtrate } \\
\text { (\% wt.) }\end{array}\end{array}$} \\
\hline $\begin{array}{l}\text { Temp. } \\
\left({ }^{\circ} \mathrm{C}\right)\end{array}$ & $\begin{array}{l}\text { Time } \\
\text { (min) }\end{array}$ & $\begin{array}{l}\text { TOC }{ }^{a} \\
(g / L)\end{array}$ & $\begin{array}{l}\text { TOC }^{b} \\
(g / L)\end{array}$ & $\begin{array}{c}\text { Solids in filtrate } \\
\text { (\% wt.) }\end{array}$ & & \\
\hline 140 & 240 & $7.61 \pm 0.22$ & $4.87 \pm 0.06$ & $1.47 \pm 0.27$ & $1.94 \pm 0.004$ & $1.64 \pm 0.01$ \\
\hline 160 & 60 & $9.22 \pm 0.07$ & $5.37 \pm 0.30$ & $1.90 \pm 0.08$ & $1.92 \pm 0.26$ & $2.83 \pm 0.26$ \\
\hline 160 & 120 & $9.10 \pm 0.09$ & $6.63 \pm 0.41$ & $1.84 \pm 0.02$ & $1.77 \pm 0.01$ & $2.63 \pm 0.14$ \\
\hline 160 & 240 & $8.36 \pm 0.35$ & $9.49 \pm 0.73$ & $1.62 \pm 0.02$ & $1.61 \pm 0.004$ & $2.27 \pm 0.09$ \\
\hline 180 & 30 & $9.03 \pm 0.11$ & $4.99 \pm 0.11$ & $1.90 \pm 0.03$ & $1.88 \pm 0.01$ & $2.22 \pm 0.01$ \\
\hline 180 & 60 & $9.37 \pm 0.06$ & $6.47 \pm 0.15$ & $1.85 \pm 0.15$ & $1.86 \pm 0.01$ & $2.15 \pm 0.002$ \\
\hline 180 & 120 & $9.24 \pm 0.04$ & $7.30 \pm 0.13$ & $1.82 \pm 0.11$ & $1.76 \pm 0.02$ & $2.04 \pm 0.68$ \\
\hline 180 & 240 & $9.09 \pm 0.08$ & $9.99 \pm 0.07$ & $1.65 \pm 0.18$ & $1.66 \pm 0.01$ & $1.98 \pm 0.004$ \\
\hline 200 & 15 & $9.50 \pm 0.05$ & $7.67 \pm 0.10$ & $1.88 \pm 0.14$ & $2.36 \pm 0.03$ & $2.64 \pm 0.03$ \\
\hline 200 & 30 & $9.06 \pm 0.16$ & $7.73 \pm 0.10$ & $1.78 \pm 0.10$ & $1.74 \pm 0.18$ & $2.16 \pm 0.01$ \\
\hline 200 & 60 & $8.43 \pm 0.30$ & $8.76 \pm 0.11$ & $1.72 \pm 0.04$ & $1.68 \pm 0.002$ & $2.07 \pm 0.004$ \\
\hline 200 & 120 & $8.13 \pm 0.28$ & $10.10 \pm 0.07$ & $1.47 \pm 0.05$ & $1.66 \pm 0.01$ & $2.00 \pm 0.21$ \\
\hline 200 & 240 & $8.57 \pm 0.02$ & $13.68 \pm 1.12$ & $1.42 \pm 0.18$ & $1.52 \pm 0.03$ & $1.96 \pm 0.001$ \\
\hline
\end{tabular}




\section{Table 2 - RSM model equations in terms of coded variables}

\begin{tabular}{ll}
\hline Parameter & Equation \\
\hline Filtrate $\left(\mathrm{m}^{3}\right)$ & \\
Cold-filtered PSS & $\mathrm{V}=6.53 \times 10^{-5}+7.42 \times 10^{-5} \mathrm{~T}+2.54 \times 10^{-5} \mathrm{t}_{\mathrm{R}}$ \\
Cold-filtered SF & $\mathrm{V}=3.28 \times 10^{-4}+1.64 \times 10^{-4} \mathrm{~T}-9.05 \times 10^{-5} \mathrm{Tt}_{\mathrm{R}}-1.93 \times 10^{-4} \mathrm{~T}^{2}$ \\
Hot-filtered SF & $\mathrm{V}=2.19 \times 10^{-4}+1.29 \times 10^{-4} \mathrm{~T}+5.03 \times 10^{-5} \mathrm{t}_{\mathrm{R}}$
\end{tabular}

Specific cake resistance $\left(\mathrm{m} \mathrm{kg}^{-1}\right)$

Cold-filtered PSS

$\alpha=1.21 \times 10^{12}-1.37 \times 10^{12} \mathrm{~T}$

Cold-filtered SF

$\alpha=1.20 \times 10^{11}-1.59 \times 10^{11} \mathrm{~T}+1.73 \times 10^{11} \mathrm{t}_{\mathrm{R}}-3.09 \times 10^{11} \mathrm{Tt}_{\mathrm{R}}$

Hot-filtered SF

$\alpha=9.78 \times 10^{11}-1.14 \times 10^{12} \mathrm{~T}-8.06 \times 10^{11} \mathrm{t}_{\mathrm{R}}+9.01 \times 10^{11} \mathrm{Tt}_{\mathrm{R}}$

Resistance of medium $\left(\mathrm{m}^{-1}\right)$

Cold-filtered PSS $\quad \mathrm{R}_{\mathrm{m}}=9.49 \times 10^{11}-9.15 \times 10^{11} \mathrm{~T}-9.79 \times 10^{11} \mathrm{t}_{\mathrm{R}}$

Hot-filtered SF

$\mathrm{R}_{\mathrm{m}}=4.37 \times 10^{11}-2.01 \times 10^{9} \mathrm{~T}$

Cake concentration ( $w / w)$
Cold-filtered PSS
$\mathrm{C}_{\mathrm{w}}=0.19+0.06 \mathrm{~T}$
Cold-filtered SF
$\mathrm{C}_{\mathrm{w}}=0.32+0.09 \mathrm{~T}+0.03 \mathrm{t}_{\mathrm{R}}$
Ho-filtered SF
$\mathrm{C}_{\mathrm{w}}=0.40+0.11 \mathrm{~T}+0.04 \mathrm{t}_{\mathrm{R}}$

Solids in filtrate (\% wt.)

Cold-filtered PSS

$$
\mathrm{s}_{\mathrm{f}}=1.82-0.21 \mathrm{~T}+0.20 \mathrm{t}_{\mathrm{R}}
$$

Cold-filtered SF

$$
\mathrm{s}_{\mathrm{f}}=1.83-0.18 \mathrm{t}_{\mathrm{R}}
$$

Hot-filtered SF

$$
\mathrm{s}_{\mathrm{f}}=2.44-0.27 \mathrm{t}_{\mathrm{R}}
$$

$\mathrm{T}$ is reaction temperature $\left({ }^{\circ} \mathrm{C}\right) ; \mathrm{t}_{\mathrm{R}}$ is reaction time $(\mathrm{min}) ; \mathrm{C}_{\mathrm{w}}$ is cake weight concentration $(\mathrm{w} / \mathrm{w})$; and $s_{\mathrm{f}}$ is solids in filtrate (\% wt.). 
Figure 1 Constant pressure filtration equipment for: (a) cold filtration of PSS; (b) cold and hot filtration of SF.

Figure 2 Effect of reaction temperature and time on filtrate volume for $\mathrm{HTC}$ at $140^{\circ} \mathrm{C}$ and $160^{\circ} \mathrm{C}$ : (a) cold filtration of PSS; (b) cold filtration of SF; (c) hot filtration of SF.

Figure 3 Effect of reaction temperature and time on filtrate volume: (a) cold filtration of PSS; (b) cold filtration of SF; (c) hot filtration of SF, for HTC at $180^{\circ} \mathrm{C}$ (a, b, c); (d) cold filtration of PSS; (e) cold filtration of SF; (e) hot filtration of SF, for HTC at $200^{\circ} \mathrm{C} \mathrm{(d,} \mathrm{e,} \mathrm{f).}$

Figure 4 Effect of reaction temperature and time on filtrate volume analysis by parabolic rate law: (a) cold filtration of PSS; (b) cold filtration of SF; (c) hot filtration of SF, for HTC at $180^{\circ} \mathrm{C}(\mathrm{a}, \mathrm{b}, \mathrm{c})$; (d) cold filtration of PSS; (e) cold filtration of SF; (f) hot filtration of SF, for HTC at $200^{\circ} \mathrm{C}(\mathrm{d}, \mathrm{e}, \mathrm{f})$.

Figure 5 Contour plot showing the effect of reaction temperature and time on specific cake resistance to filtration: (a) cold filtration of PSS; (b) cold filtration of SF; (c) hot filtration of SF.

Figure 6 Contour plot showing the effect of reaction temperature and time on resistance of filter medium: (a) cold filtration of PSS; (b) cold filtration of SF; (c) hot filtration of SF.

Figure 7 Contour plot showing the effect of reaction temperature and time on cake concentration: (a) cold filtration of PSS; (b) cold filtration of SF; (c) hot filtration of SF.

Figure 8 Plots of observed values from experiment and predicted optimised values from the models: (a) specific cake resistance (b) resistance of medium; (c) cake concentration; and (d) solids in filtrate. 


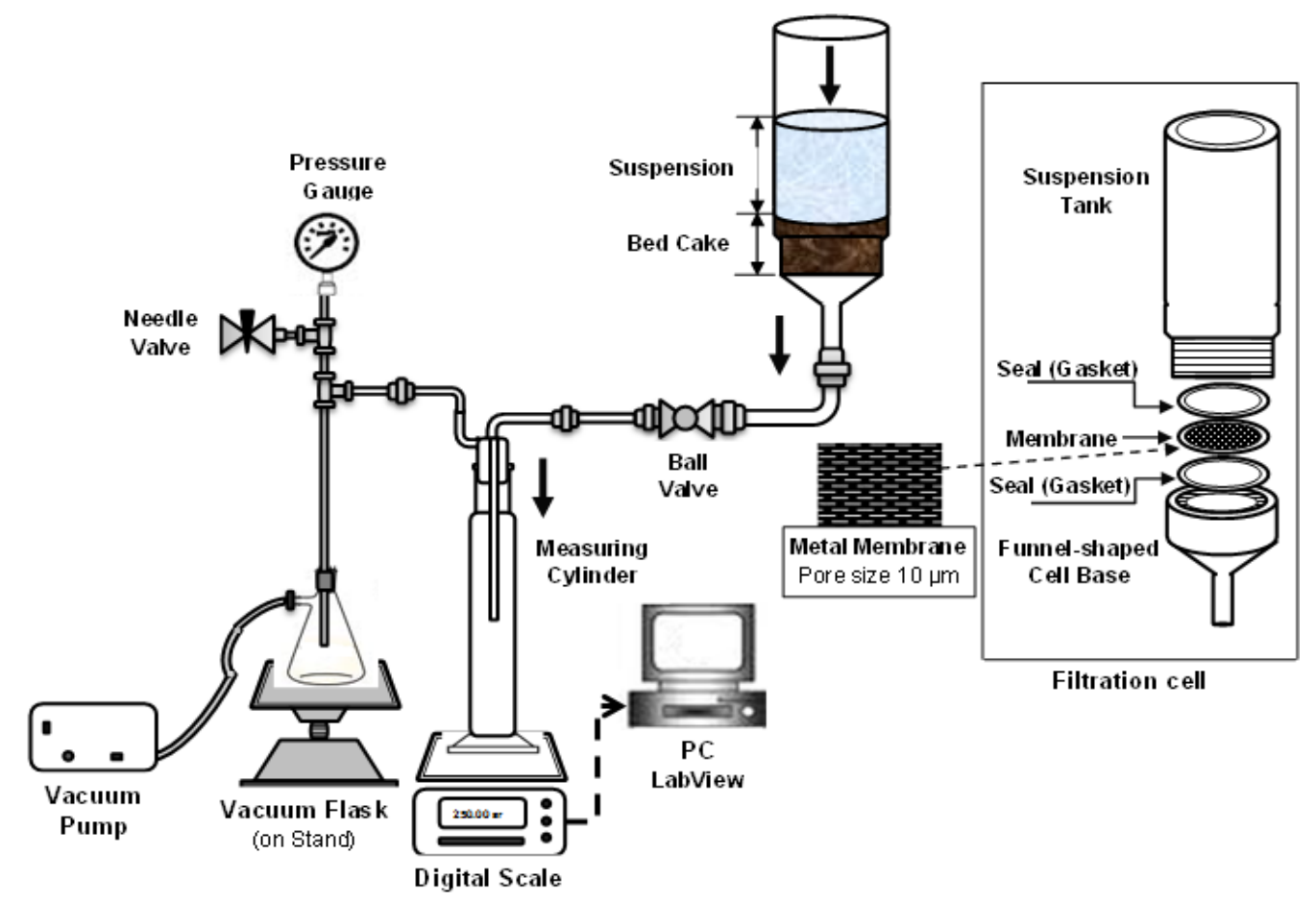

648

649

(b)

650

651

652

653

654

655

656

657

658

659

660

661

662

663

664

665

666

667

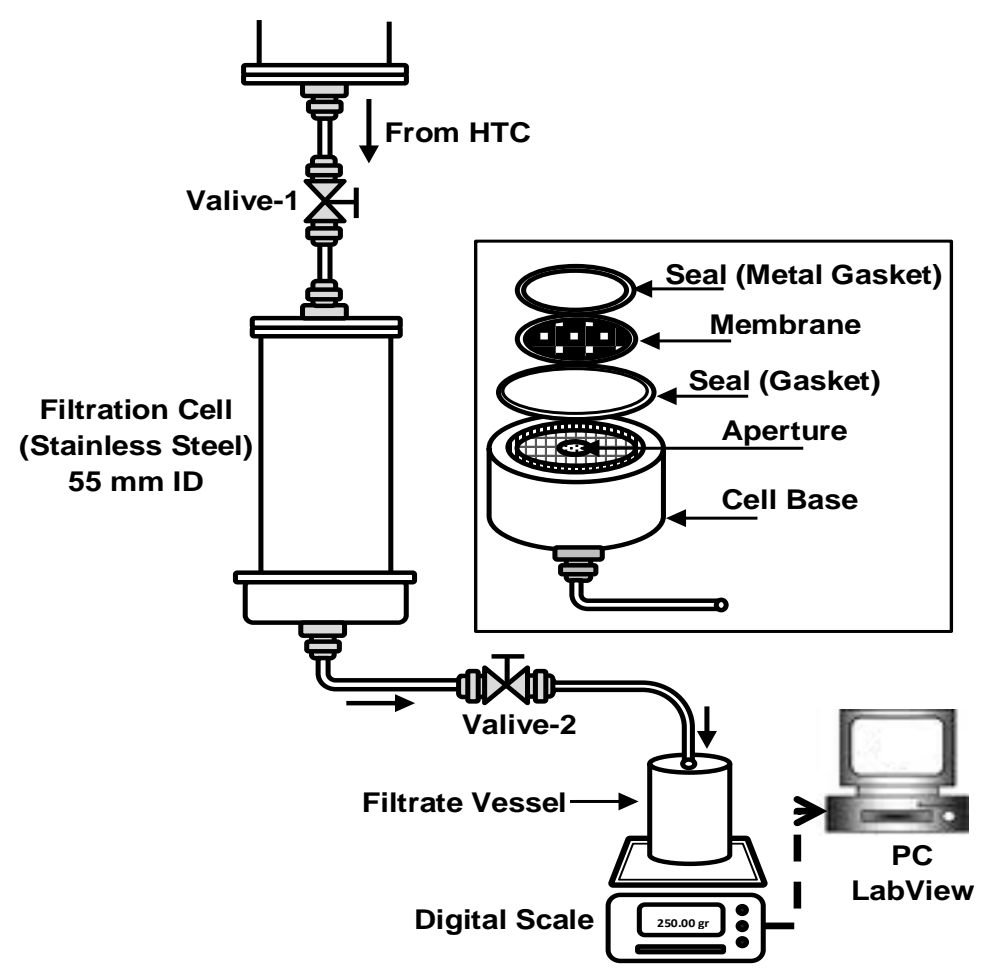

Figure 1 - Constant pressure filtration equipment for: (a) cold filtration of PSS; (b) cold and hot filtration of SF. 

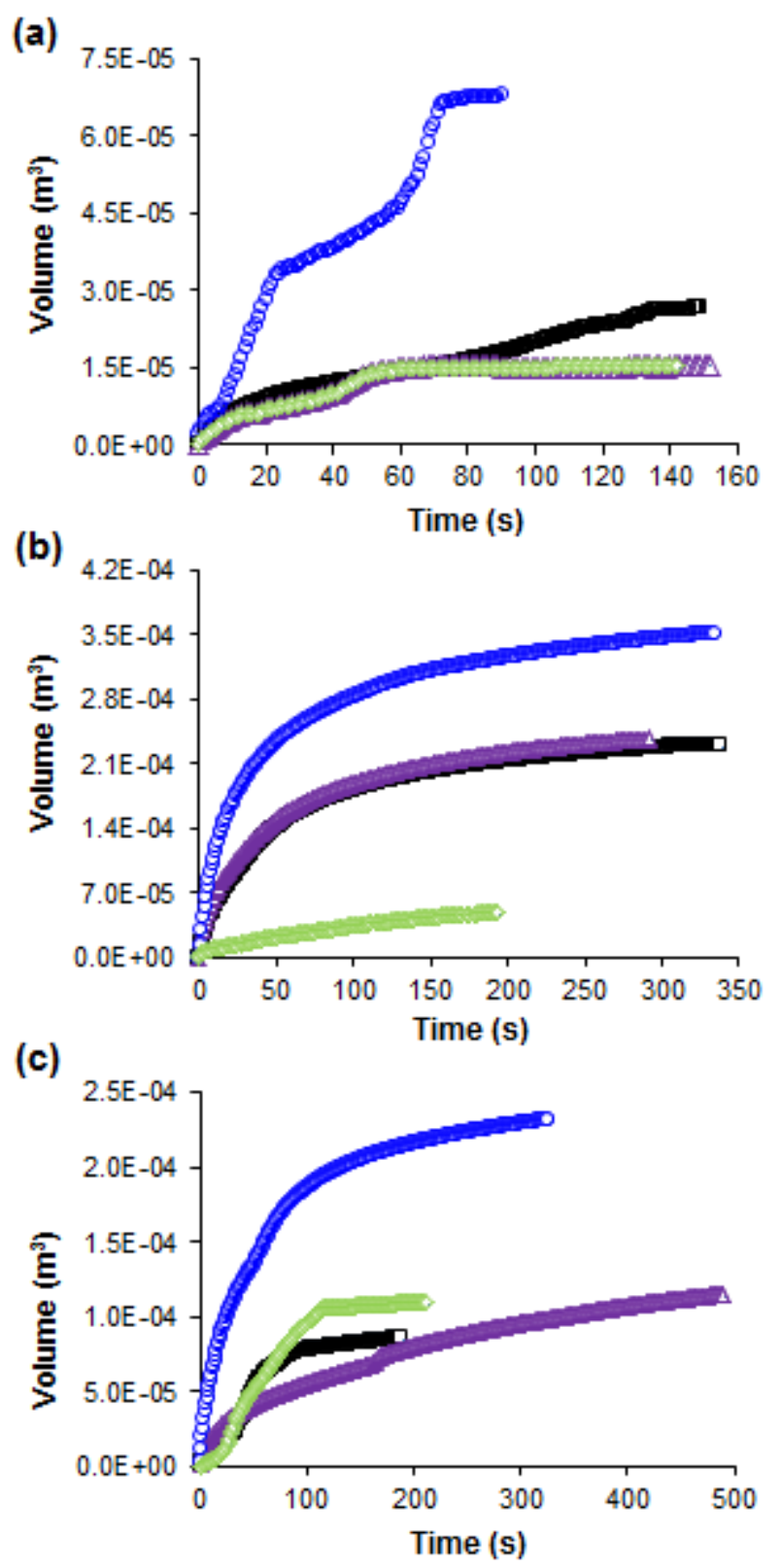

675 Figure 2 - Effect of reaction temperature and time on filtrate volume for HTC at $140^{\circ} \mathrm{C}$ and $676160^{\circ} \mathrm{C}$ : (a) cold filtration of PSS; (b) cold filtration of SF; (c) hot filtration of SF. 

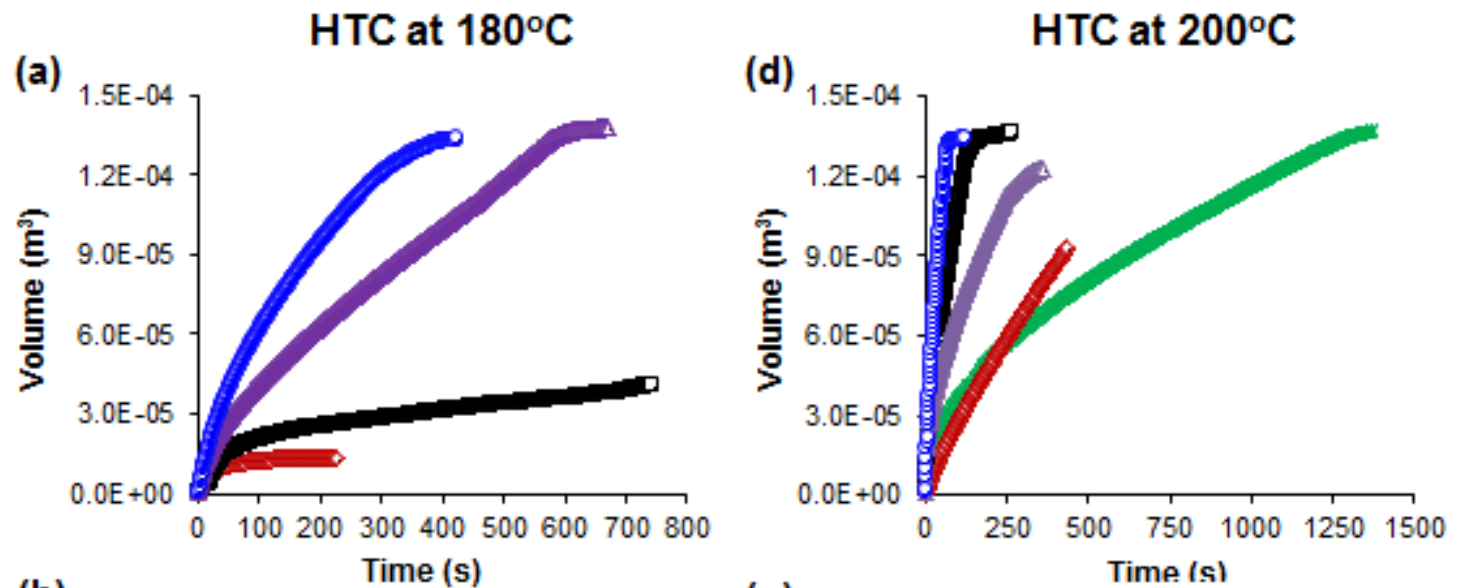

(b) Time (s)

689

690

691

692

693

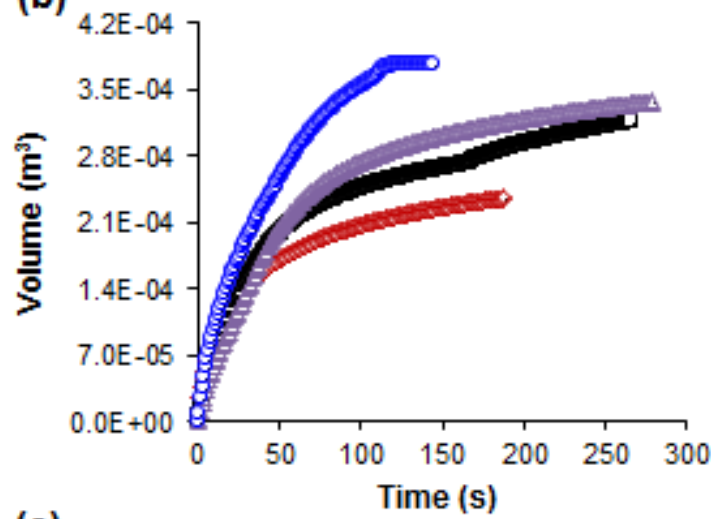

694

(c) $3.9 \mathrm{E}-04$

695

696

697

698

699

700

701

702

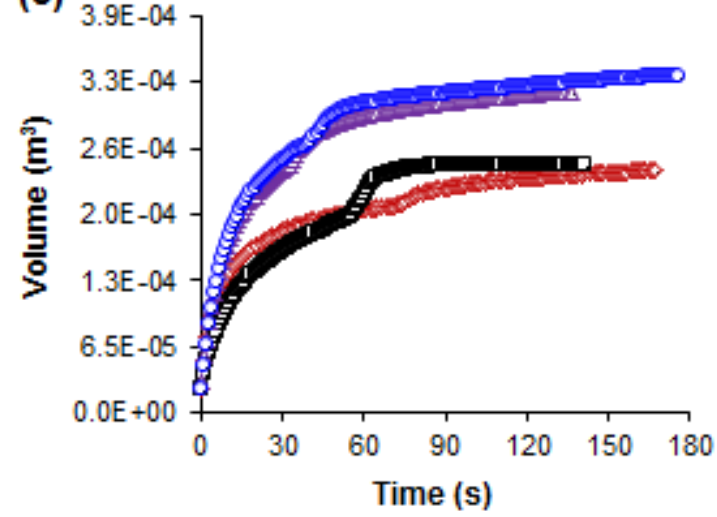

(e) Time (s)
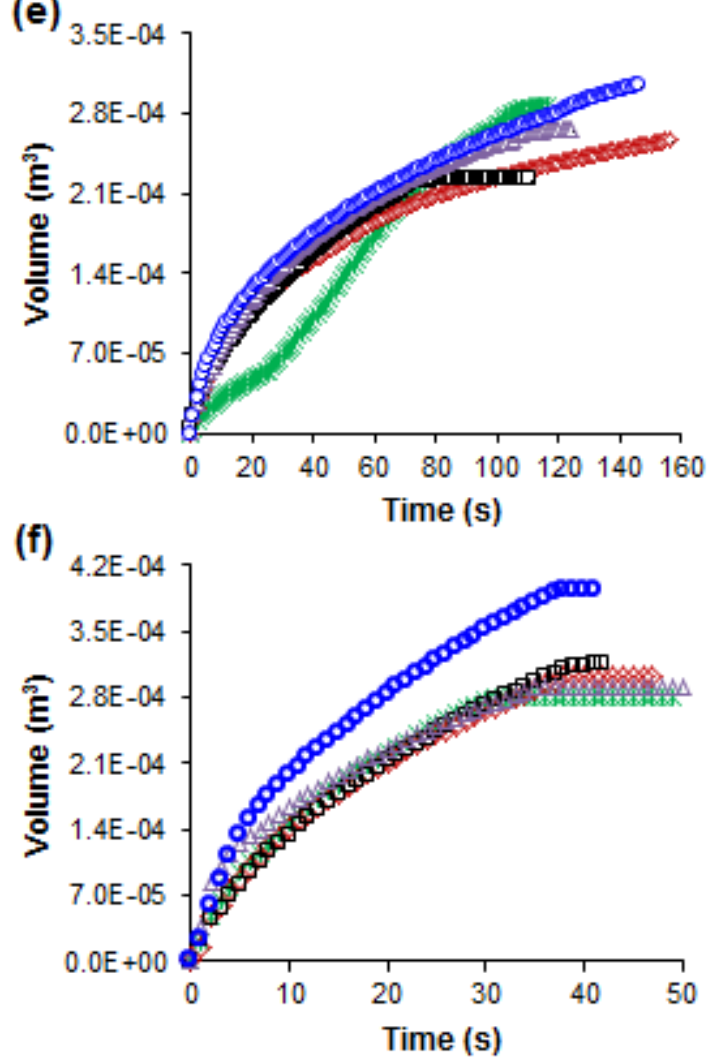

$\mathrm{HTC}$ at $180^{\circ} \mathrm{C}$
$30 \mathrm{~min}$ Treatment Time
$\square 60 \mathrm{~min}$ Treatment Time
$\Delta 120 \mathrm{~min}$ Treatment Time
$\circ 240 \mathrm{~min}$ Treatment Time

703

HTC at $200^{\circ} \mathrm{C}$ * 15 min Treatment Time $\diamond 30$ min Treatment Time $\square 60$ min Treatment Time $\Delta 120$ min Treatment Time O240 min Treatment Time

704 Figure 3 - Effect of reaction temperature and time on filtrate volume: (a), (d) cold filtration of PSS; (b), (e) cold filtration of SF; (c), (f) hot filtration of SF. 

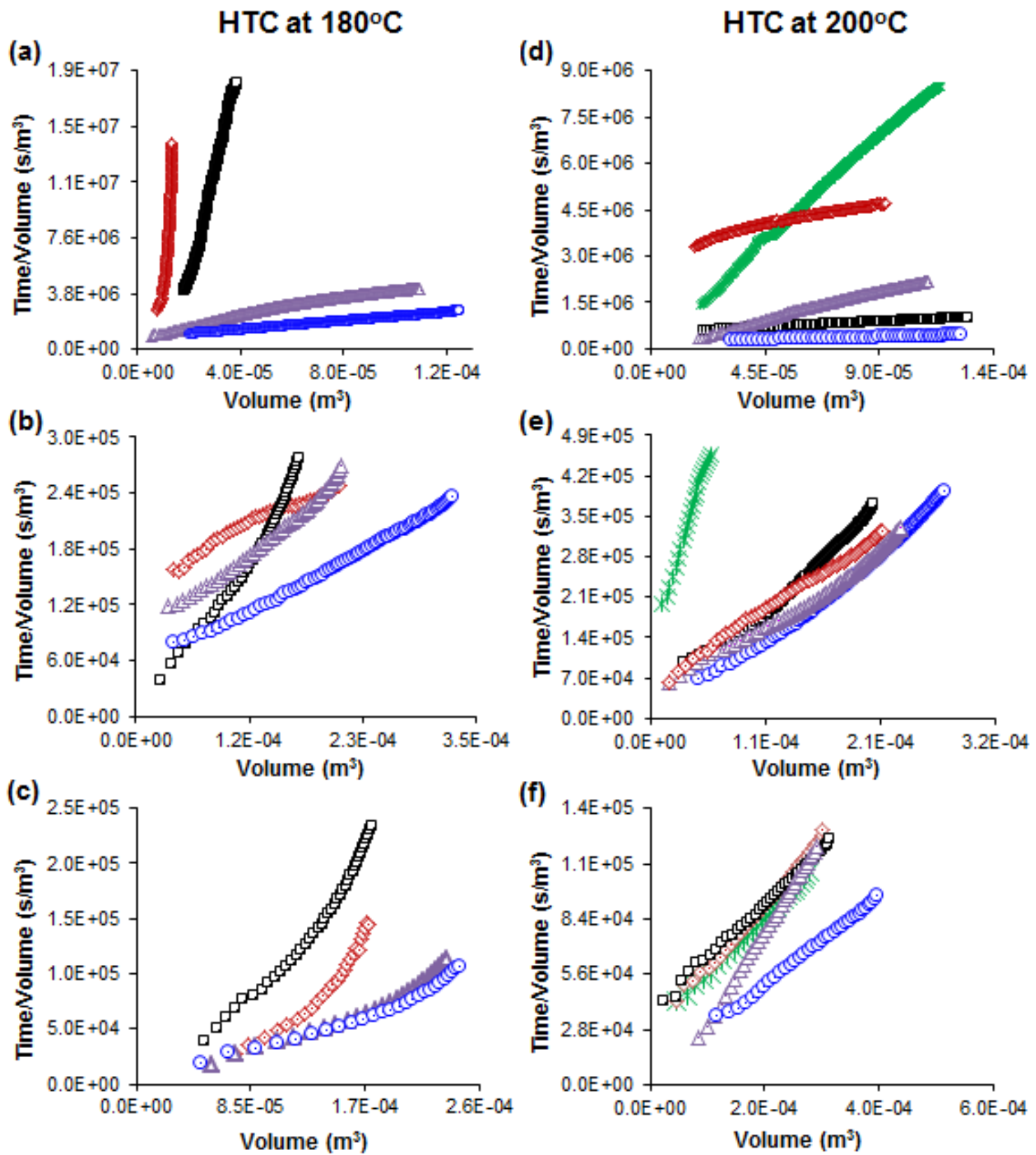

\begin{tabular}{|l|}
\hline HTC at $180^{\circ} \mathrm{C}$ \\
$\diamond 30$ min Treatment Time \\
$\square 60$ min Treatment Time \\
$\triangle 120$ min Treatment Time \\
$\circ 240$ min Treatment Time
\end{tabular}

Figure 4 - Effect of reaction temperature and time on filtrate volume analysis by parabolic

709 rate law: (a), (d) cold filtration of PSS; (b), (e) cold filtration of SF; (c), (f) hot filtration of

710 SF. 

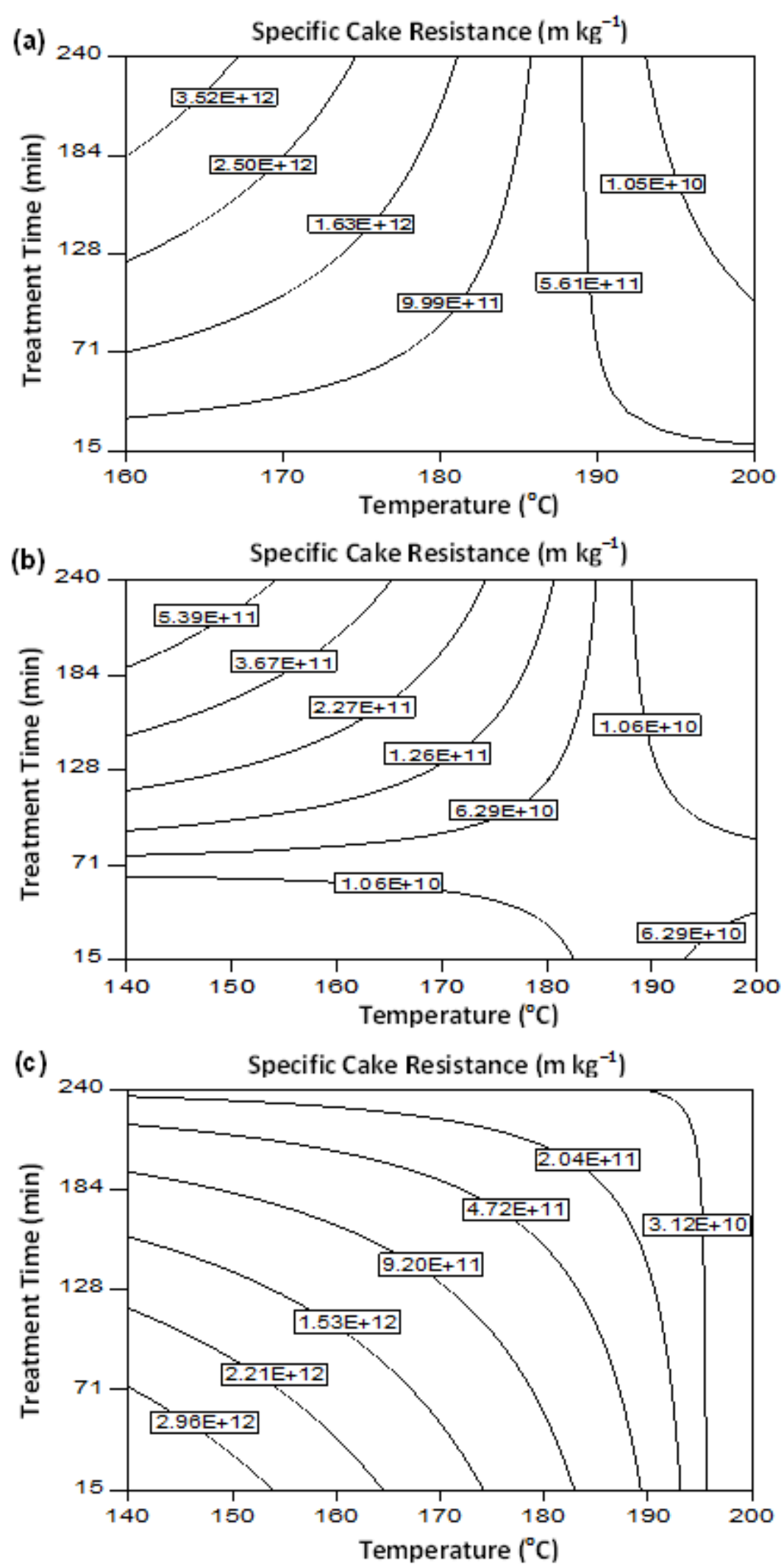

712 Figure 5 - Contour plot showing the effect of reaction temperature and time on specific cake 713 resistance to filtration: (a) cold filtration of PSS; (b) cold filtration of SF; (c) hot filtration of 714 SF. 

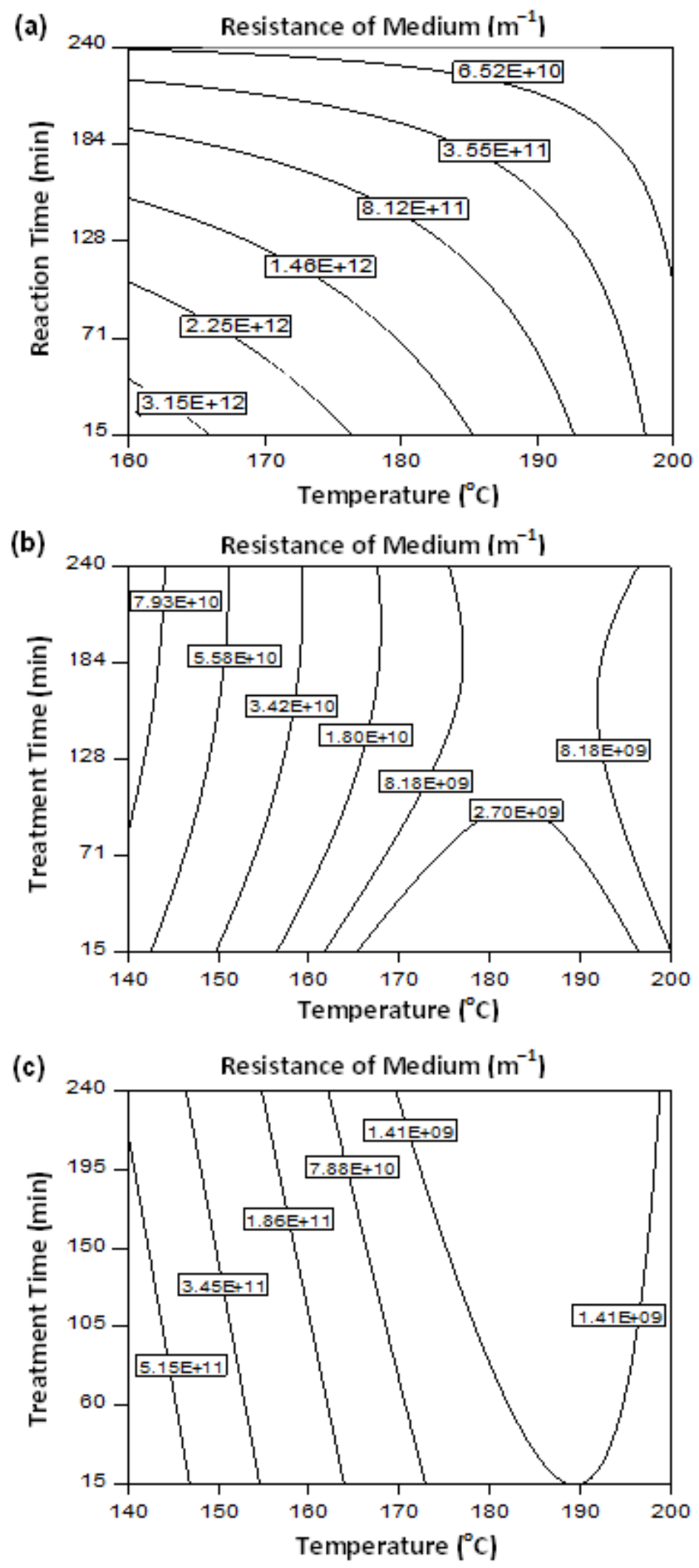

716 Figure 6 - Contour plot showing the effect of reaction temperature and time on resistance of

717 filter medium: (a) cold filtration of PSS; (b) cold filtration of SF; (c) hot filtration of SF. 

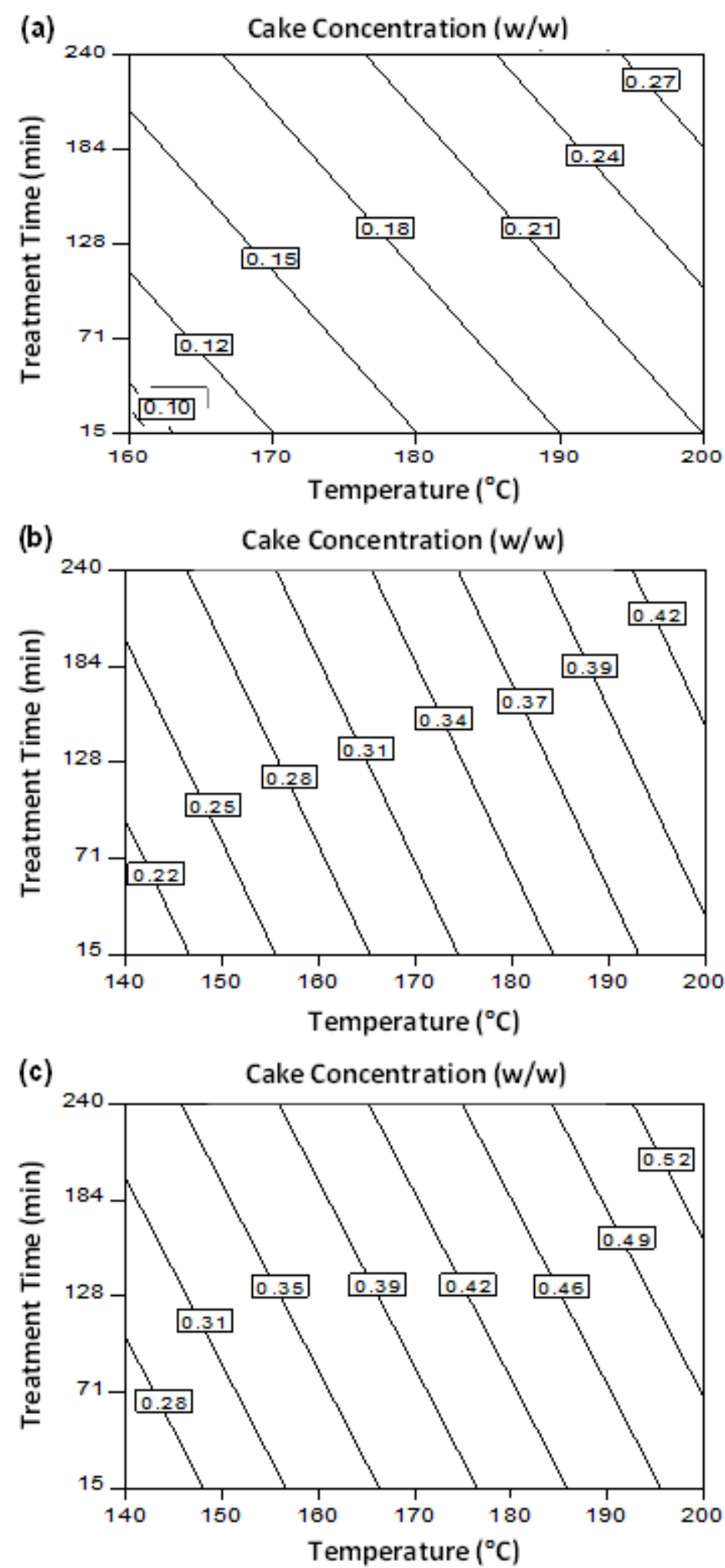

720 Figure 7 - Contour plot showing the effect of reaction temperature and time on cake

721 concentration: (a) cold filtration of PSS; (b) cold filtration of SF; (c) hot filtration of SF. 
(a)

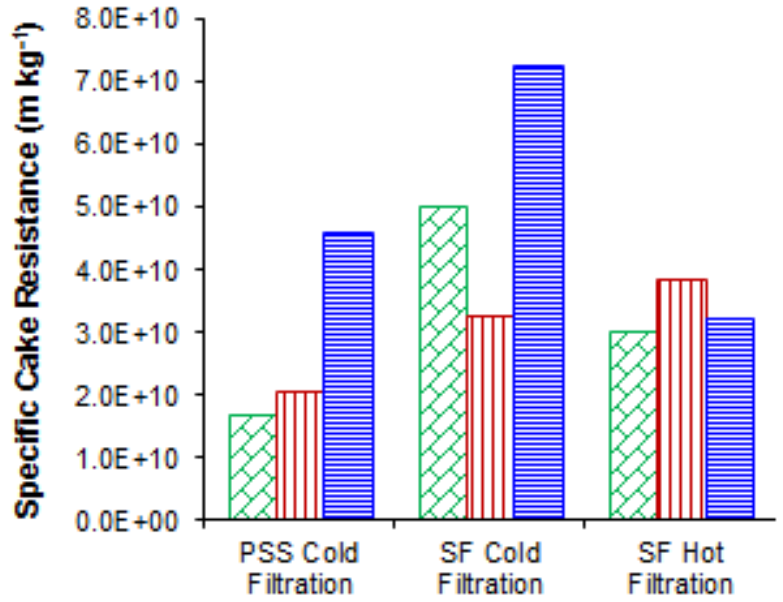

Experiment

(b)

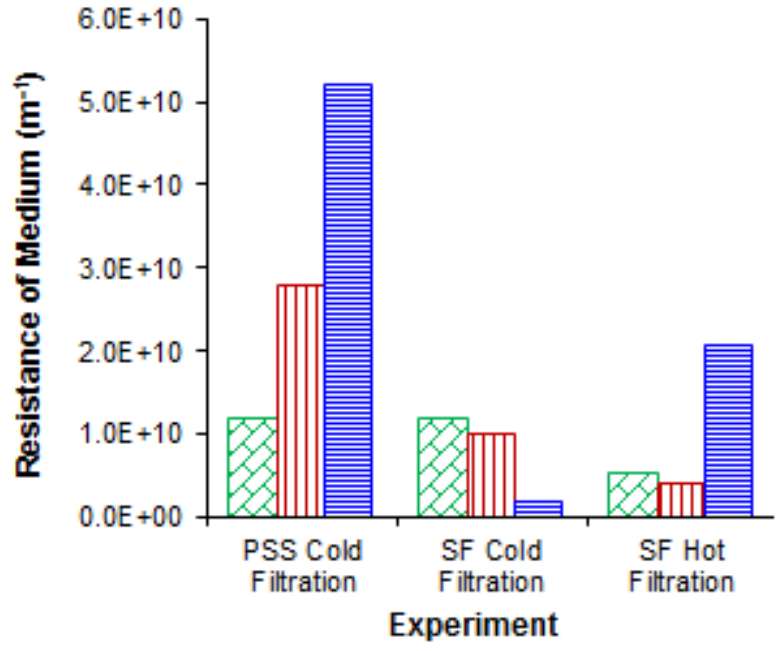

\CCRD (200 deg for $240 \mathrm{~min}$ ) ๓Validation-1 (200 deg C for $240 \mathrm{~min}$ ) घValidation-2 (200 deg $\mathrm{C}$ for $60 \mathrm{~min}$ ) (c)

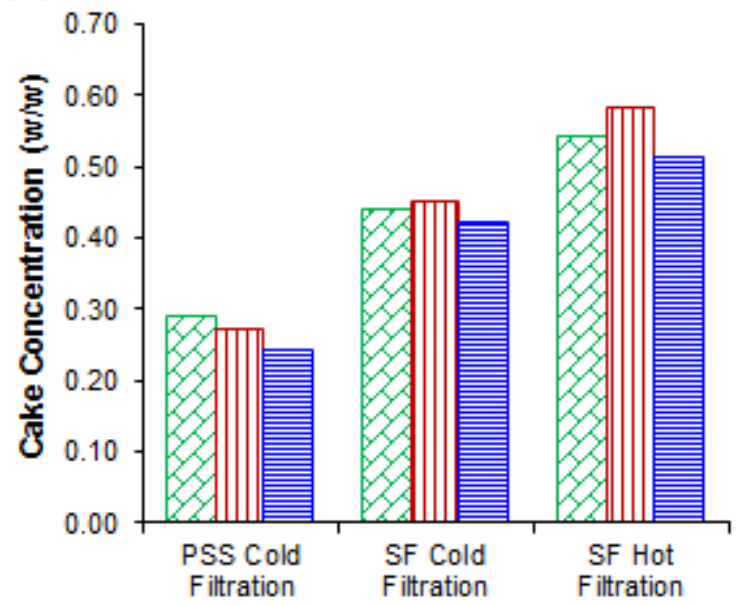

Experiment

(d)

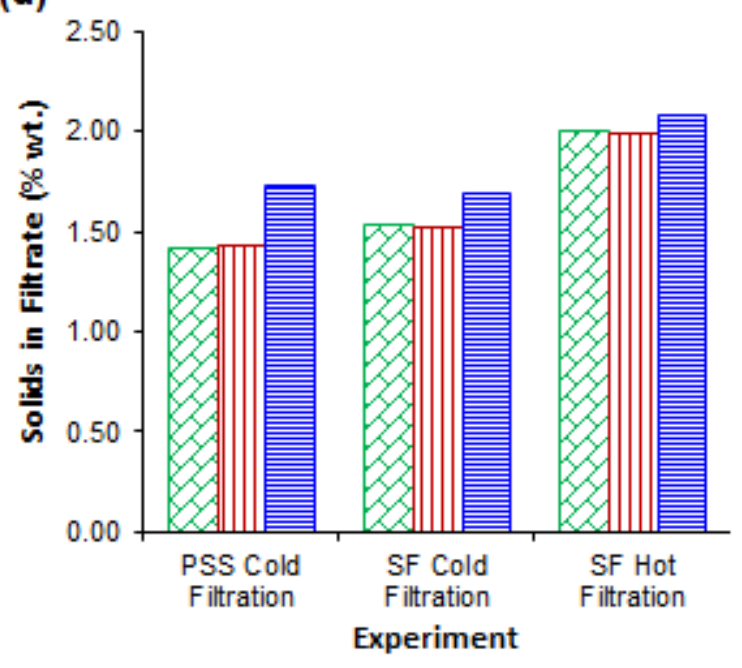

$\square$ CCRD (200 deg for $240 \mathrm{~min}$ ) ๓Validation-1 (200 deg C for $240 \mathrm{~min}$ ) 目Validation-2 (200 deg C for $60 \mathrm{~min}$ )

Figure 8 - Plots of observed values from experiment and predicted optimised values from the

727 models: (a) specific cake resistance (b) resistance of medium; (c) cake concentration; and (d) 728 solids in filtrate. 